\title{
Response of spores and young gametophytes of Cyathea delgadii Sternb. (Cyatheaceae) and Blechnum brasiliense Desv. (Blechnaceae) to different light levels
}

\author{
Rosane Hiendlmeyer ${ }^{1}$ and Aurea Maria Randi ${ }^{1,2}$
}

Received: July 24, 2006. Accepted: March 27, 2007

\begin{abstract}
RESUMO -(Resposta de esporos e gametófitos jovens de Cyathea delgadii Sternb. (Cyatheaceae) e Blechnum brasiliense Desv. (Blechnaceae) aos diferentes níveis de luz). Luz é um dos fatores limitantes para o estabelecimento das pteridófitas, pois controla a germinação de esporos fotossensíveis. O objetivo deste trabalho foi estudar o efeito de níveis de luz na germinação de esporos de duas pteridófitas ornamentais nativas da Floresta Atlântica, sob condições ambientais. Cyathea delgadii é uma samambaia arbórea e Blechnum brasiliense, subarborescente. O efeito dos níveis de luz foi analisado em abril e em junho/2003, em Florianópolis, SC, Brasil. Esporos esterilizados foram inoculados em "erlenmeyers" contendo meio de cultura composto por macronutrientes, ferro e benomil a $0,01 \%$. Os frascos foram mantidos em caixas de $50 \mathrm{~cm}^{3}$ cobertas por tela "sombrite" que forneceu 5, 22, 42 e $62 \%$ de luz natural. Irradiâncias e temperaturas foram medidas diariamente às $14 \mathrm{~h}$ no período de estudo. As maiores porcentagens de germinação foram observadas sob 5 e $22 \%$ de luz solar para ambas as espécies. A germinação de esporos de Cyathea delgadii sob 22\% de luz atingiu 76\% e o tempo médio de germinação foi de 19,7 dias; a 5\% de luz a germinação atingiu 83,5\% e o tempo médio de germinação foi de 20,16 dias. A germinação de Blechnum brasiliense sob $22 \%$ de luz atingiu $76 \%$ e o tempo médio de germinação foi de 9,06 dias; a 5\% de luz a germinação atingiu 84\% e o tempo médio de germinação foi de 13,18 dias. Os maiores níveis de luz inibiram parcialmente a germinação e os gametófitos morreram no decorrer do período de teste.
\end{abstract}

Palavras-chave: esporos, fotoinibição, germinação, níveis de luz, pteridófitas

\begin{abstract}
Response of spores and young gametophytes of Cyathea delgadii Sternb. (Cyatheaceae) and Blechnum brasiliense Desv. (Blechnaceae) to different light levels). Light is a limiting factor for fern stablishment because it controls germination of light sensitive spores. The aim of this work was to study the effect of light levels on spore germination in two ornamental ferns native to the Atlantic forest, under natural conditions. Cyathea delgadii is a tree fern and Blechnum brasiliense, a subarborescent fern. The effect of light levels was analyzed in April and July/2003, in Florianópolis, Santa Catarina state, Brazil. Sterilized spores were sown in Erlenmeyer flasks containing mineral culture medium with macronutrients, iron, and benomyl $0.01 \%$. The Erlenmeyer flasks were kept in $50 \mathrm{~cm}^{3}$ boxes covered with black shade netting, which gave 5, 22, 42, and 62\% natural light. Irradiance and temperature were scored daily at 14:00 $\mathrm{h}$ during the study period. Higher percentages of germination were observed at 5 and $22 \%$ light for both species. Germination of $C y a t h e a$ delgadii spores at 22\% light reached $76 \%$ and mean germination time was 19.7 days; at 5\% light, germination reached $83.5 \%$ and mean germination time was 20.16 days. Germination of Blechnum brasiliense at $22 \%$ light reached $76 \%$ and mean germination time was 9.06 days; at 5\% light, germination reached $84 \%$ and mean germination time was 13.18 days. The highest light levels inhibited spore germination and the gametophytes died during the test period.
\end{abstract}

Key words: ferns, germination, light levels, photoinhibition, spores

\section{Introduction}

Ferns are an important plant group of the Brazilian flora. According to Tryon (1970; 1972) and Tryon \& Tryon (1982), southeastern Brazil (from Minas Gerais to Rio Grande do Sul) contains about 600 species. Sehnem (1977) analyzed the geographic distribution, ecology, and fern migration routes in southern Brazil; he observed a broad fern distribution with some cosmopolitan species, which also occurred on several continents. According to the author, in natural conditions ferns basically require shade and high humidity for their development.

Some Brazilian ferns are used as ornamental plants and members of the Cyatheaceae and Dicksoniaceae have been indiscriminately exploited by commercialization of pots and substrate used in the production of ornamental plants (Fernandes 2000; Windisch 2002). For this reason, understanding fern ecophysiology is necessary for the development of methods that may assist in their conservation and management.

\footnotetext{
1 University of Santa Catarina, Department of Botany, Postal Box 476, 88040-900 Florianópolis, SC, Brazil

2 Corresponding Author: amrandi@ @cb.ufsc.br
} 
910 Hiendlmeyer \& Randi: Response of spores and young gametophytes of Cyathea delgadii Sternb. (Cyatheaceae)...

Light has signaling functions for any given plant's development in the forest and is the energy source for $\mathrm{CO}_{2}$ assimilation (Lüttge 1997). According to Chazdon $\&$ Fetcher (1984), 0.5 to $4 \%$ sunlight reaches the forest floor. The effect of light on the induction of fern spore germination has been extensively studied for many years. It has been known for a long time that light promotes spore germination through a low fluency response (LFR) mediated by the phytochrome system (Sugai \& Furuya 1967; 1968; Miller 1968; Furuya 1983; 1985; Raghavan 1993). In spite of this, the international literature has very little information concerning the effects of light levels on spore germination. Inhibition of spore germination at high light levels was observed for spores of Dicksonia sellowiana Hook. (Dicksoniaceae) and Rumohra adiantiformis (G. Forst.) Ching (Dryopteridaceae) (Filippini et al. 1999; Brum \& Randi 2002; Renner \& Randi 2004).

This paper investigated the effect of light levels on germination and gametophyte survival of two ornamental fern species from the Atlantic Forest, under natural conditions. Cyathea delgadii Sternb. (Cyatheaceae) is a tree fern of gallery, montane, cloud, and rain forests (Tryon \& Tryon 1982). Blechnum brasiliense Desv. (Blechnaceae) is a subarborescent fern, which also occurs in a wide variety of environments, including cloud forests, lowland rain forests, gallery forests, swamps and savannahs (Tryon \& Tryon 1982).

\section{Material and methods}

Sporophylls of several Cyathea delgadii Sternb. and Blechnum brasiliense Desv. plants were harvested in February/2002 along a path in the São Francisco de Assis Natural City Park, situated in Blumenau, Santa Catarina state ( $\left.26^{\circ} 55^{\prime} 15^{\prime \prime} \mathrm{S} ; 49^{\circ} 05^{\prime} 30^{\prime \prime} \mathrm{W}\right)$. The study site is a 22.29-hectare natural Atlantic forest fragment. Sporophylls were air-dried in an oven at $30^{\circ} \mathrm{C}$ for three days on filter paper in order to induce dehiscence. The spores were removed and separated from debris by filtering through lens paper, and stored in glass jars under refrigeration at $7 \pm 1^{\circ} \mathrm{C}$.

Spores were surface-sterilized using a $10 \%(\mathrm{v} / \mathrm{v})$ solution of commercial bleach ( $2 \%$ active chlorine) for a period of $20 \mathrm{~min}$. after which they were filtered through sterile filter paper and washed several times with sterile distilled water. Spores were sown in Erlenmeyer flasks containing $20 \mathrm{~mL}$ of mineral solution as proposed by Mohr (1956), modified by Dyer (1979) and supplemented with benomyl $0.01 \%$. The flasks were plugged with two layers of autoclaved, transparent, commercial polypropylene film $(7 \times 7 \mathrm{~cm})$ fixed with a rubber band. All procedures were carried out in a laminar hood.

For the study of the effects of light levels, four Erlenmeyer flasks per treatment (four replications) were inoculated with surface sterilized spores $(10 \mathrm{mg})$ and kept in $50 \mathrm{~cm}^{3}$ boxes covered with black shade netting that provided $62,42,22$, and $5 \%$ natural light. A maximum and minimum thermometer was placed inside the boxes. Minimum and maximum temperatures were recorded daily at 14:00 $\mathrm{h}$. Irradiance inside the boxes was also recorded daily at 14:00 h. Irradiance levels were measured with a quantameter LICOR 250, using a PAR sensor (400 to $700 \mathrm{~nm}$ ). The boxes were kept in an open area. The tests were carried out from 1-30 April 2003 for Cyathea delgadii and from 13 June to 1 July 2003 for Blechnum brasiliense, in Florianópolis, Santa Catarina state, Brazil. During the test period, light levels were measured in the São Francisco de Assis Natural City Park.

All tests were done in a completely randomized design. The percentage of germination was scored every three days for Cyathea delgadii and daily for Blechnum brasiliensis. Each observation was based on one slide analyzed from each flask per treatment, and 100 spores or young gametophytes counted on each slide. Spores were considered germinated when a rhizoidal cell protrusion was present. Gametophytes were considered alive when green protallial cells were present and were considered dead when the protallial cells were discolored or light-brown. Mean germination time was calculated for each replication per treatment according to the equation: $\bar{t}=\sum_{i=1}^{k} n_{i} t_{i} / \sum_{i=1}^{k} n_{i}$, where $t_{i}$ is the time in days from sowing to the last observation and $n_{i}$ is the number of spores completing the germination process on day $t_{i}$ (Labouriau 1983; Santana \& Ranal 2004). The Kolmogorov-Smirnov test showed absence of normality for the germinability data, which were submitted to arcsine transformation. The KolmogorovSmirnov and Bartlett's tests $(=0.05)$ were also applied to the transformed data, before the analysis of variance. To compare the effect of light levels on mean germination time and on maximum germinability, pairwise comparisons were done using Tukey test at 0.05 significance (Santana \& Ranal 2004). To compare the effects of light levels between germinability and survivor gametophytes of Cyathea delgadii and Blechnum brasiliense the Student $t$ test was applied at the end of the test period. 


\section{Results}

The data obtained for Blechnum brasiliense spore germination under different light levels showed that during the test period, which occurred from 13 June to 1 July ( 1 to 20 days of cultivation), minimum temperatures in Florianópolis ranged from 14 to $19^{\circ} \mathrm{C}$ and maximum temperatures from 21 to $32^{\circ} \mathrm{C}$ (Fig. 1A). Data obtained in the São Francisco de Assis Natural City Park showed that $0.9 \%$ natural sunlight reaches the floor of this Atlantic forest fragment. During the test period, irradiance at 14:00 $\mathrm{h}$ varied from 6 to 49 $\mu \mathrm{mol} \mathrm{m} \mathrm{s}^{-2} \mathrm{~s}^{-1}$ (5\% light); from 28 to $215 \mu \mathrm{mol} \mathrm{m}^{-2} \mathrm{~s}^{-1}(22 \%$ light); from 53 to $411 \mu \mathrm{mol} \mathrm{m}^{-2} \mathrm{~s}^{-1}$ (42\% light) and finally, from 78 to $606 \mu \mathrm{mol} \mathrm{m}^{-2} \mathrm{~s}^{-1}$ (62\% light) (Fig. 1B). Lower irradiance values were observed on the first and after the seventh day of Blechnum brasiliense spore cultivation, which were rainy days. Lower percentages of Blechnum brasiliense germination were observed at 62 and $42 \%$ and higher at 22 and 5\% light (Tab. 1, Fig. 1C). The lowest mean germination time was found at $62 \%$ light (Tab. 1). Gametophyte survival began to decrease after 11 days of cultivation at $62 \%$ light during the test period (Fig. 2A).

Data for spore germination of Cyathea delgadii under different light levels were obtained in April/2003. During the test period, minimum daily temperatures in Florianópolis ranged from 9 to $23^{\circ} \mathrm{C}$, maximum daily temperatures ranged from 28 to $36^{\circ} \mathrm{C}$ (Fig. 3A) and irradiance values at $14: 00 \mathrm{~h}$ varied from 12 to $64 \mu \mathrm{mol} \mathrm{m}{ }^{-2} \mathrm{~s}^{-1}$ (5\% light); from 55 to $284 \mu \mathrm{mol} \mathrm{m}^{-2} \mathrm{~s}^{-1}$ (22\% light); from 163 to $542 \mu \mathrm{mol} \mathrm{m}^{-2} \mathrm{~s}^{-1}$ (42\% light); and from 241 to $800 \mu \mathrm{mol} \mathrm{m}^{-2} \mathrm{~s}^{-1}$ (62\% light) (Fig. 3B). The third day of Cyathea delgadii cultivation was very cloudy and rainy, and had the lowest irradiance of the test period. Lower percentages of Cyathea delgadii germination were observed at 62 and $42 \%$ light and higher were observed at 22 and 5\% light, which did not differ statistically (Tab. 1, Fig. 3C). The lowest mean germination time was found at $62 \%$ light (Tab. 1). After a few days of cultivation, the percentage of Cyathea delgadii gametophyte survival decreased at 62 and $42 \%$ light (Fig. 2B).

\section{Discussion}

The first observation of this study was germinability photoinhibition at higher light levels. There was wide daily alternation between minimum and maximum temperatures over the test period; some days were very warm and some nights very cold. On some days, the difference between daytime and nocturnal temperatures was over $15^{\circ} \mathrm{C}$. On windy days, higher temperatures were observed inside the $5 \%$ light box and lower temperatures inside the $62 \%$ light box. This was probably a consequence of air circulation inside the boxes, considering that the box which received $62 \%$ sunlight was more ventilated due to the larger holes in the black shade netting. According to Haupt (1990; 1991; 1992) phytochrome-mediated spore germination in Dryopteris filix-mas L. and D. paleacea $(\mathrm{Sw})$ C. Chr. (Dryopteridaceae) was inhibited by raising the temperature from 22 to 27 or $32{ }^{\circ} \mathrm{C}$; the elevated

A
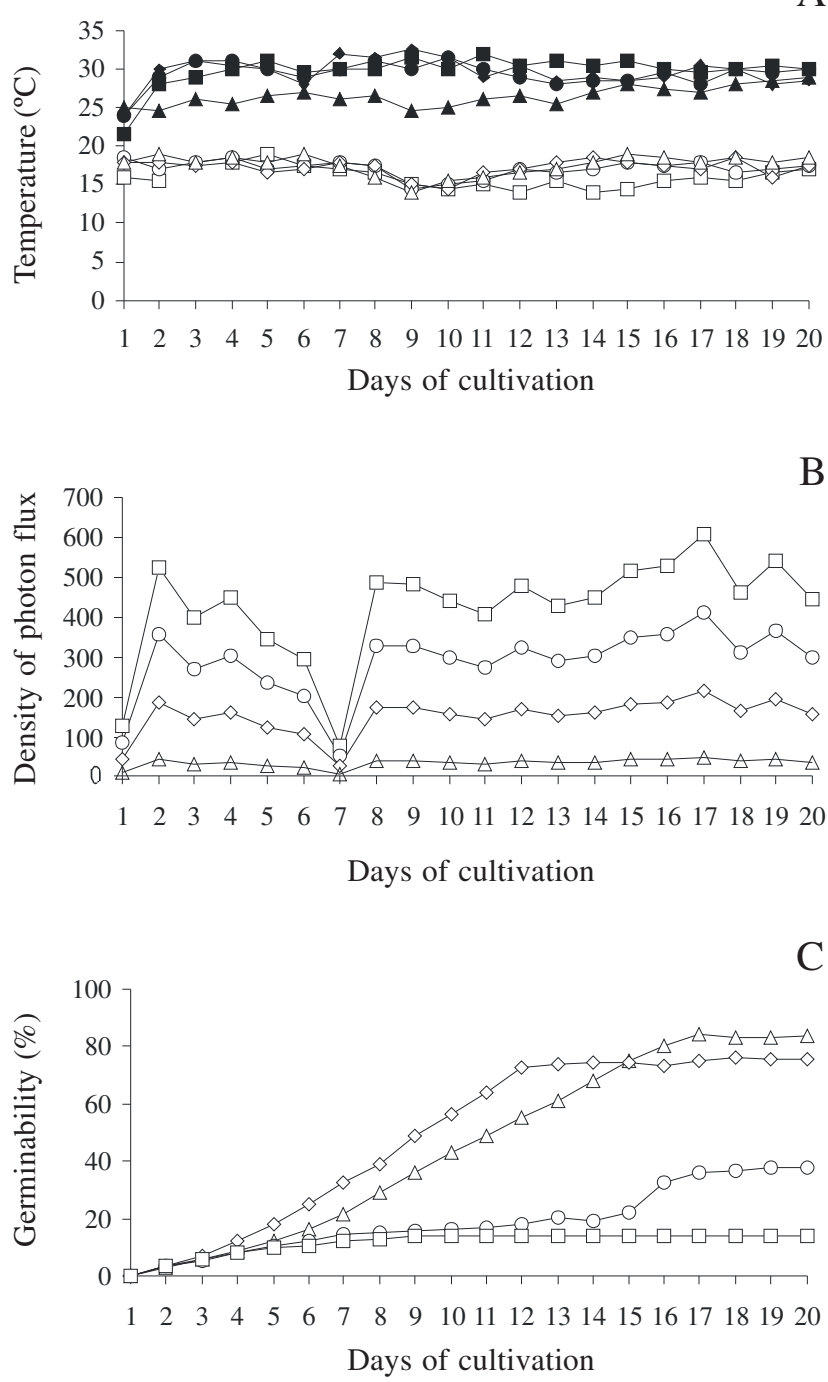

Figure 1. Minimum and maximum temperature (A) and irradiance $\left(\mu \mathrm{mol} \mathrm{m} \mathrm{s}^{-2} \mathrm{~s}^{-1}\right)(\mathrm{B})$ measured at 14:00 $\mathrm{h}$, inside boxes of black shade netting where spores were kept to provide different light levels from 13 of June to 01 of July (B); germinability of Blechnum brasiliense Desv. (C). Open symbols are minimum temperatures and dark symbols are maximum temperatures $(\square=62 \%$ light; $\circ=42 \%$ light $; \diamond=22 \%$ light $: \triangle 5 \%$ light . 
912 Hiendlmeyer \& Randi: Response of spores and young gametophytes of Cyathea delgadii Sternb. (Cyatheaceae)...

Table 1. Days to reach maximum germination, mean germination time, and final percentage of germination of Blechnum brasiliense and Cyathea delgadii Sternb. spores under different light levels. DMG = days to reach maximum germination; MGT = mean germination time; $\mathrm{MG}=$ maximum percentage of germination. Mean \pm standard deviation. $\chi^{2}=$ statistic of Bartlett's test for variances; $D_{\max }=$ statistic of the Kolmogorov-Smirnov test for normality $(\mathrm{n}=16, \alpha=0.05, \delta=0.5)$. Lines with different letters denote statistical differences (Tukey test). *After angular transformation.

\begin{tabular}{|c|c|c|c|c|}
\hline \multirow{2}{*}{$\begin{array}{c}\text { Characteristics and } \\
\text { statistical assumptions }\end{array}$} & \multicolumn{4}{|c|}{ Light level (\%) } \\
\hline & 62 & 42 & 22 & 5 \\
\hline & \multicolumn{4}{|c|}{ Blechnum brasiliense } \\
\hline DMG & 9 & 20 & 18 & 17 \\
\hline $\begin{array}{l}\text { MGT (days) } \\
\chi^{2}=6.512 \\
D=0.165\end{array}$ & $6.9 \pm 0.211 \mathrm{a}$ & $13.92 \pm 0.30 c$ & $9.06 \pm 0.112 b$ & $13.18 \pm 0.05 c$ \\
\hline $\begin{array}{l}\mathrm{MG}(\%) \\
* \chi^{2}=4.903 \\
* D_{\max }=0.156\end{array}$ & $13.5 \pm 0.96 \mathrm{c}$ & $37.75 \pm 2.22 b$ & $76.00 \pm 4.24 \mathrm{a}$ & $84.00 \pm 0.82 a$ \\
\hline $\mathrm{DMG}$ & 12 & \multicolumn{2}{|c|}{ Cyathea delgadii } & 30 \\
\hline $\begin{array}{l}\text { MGT (days) } \\
\chi^{2}=3.960 \\
D_{\max }=0.171\end{array}$ & $8.36 \pm 0.47 \mathrm{a}$ & $14.68 \pm 0.41 b$ & $19.74 \pm 0.14 \mathrm{c}$ & $20.16 \pm 0.23 c$ \\
\hline $\begin{array}{l}\mathrm{MG}^{\max }(\%) \\
* \chi^{2}=1.701 \\
* D_{\max }=0.158\end{array}$ & $23.0 \pm 6.68 \mathrm{c}$ & $40.25 \pm 4.03 b$ & $76.00 \pm 3.46 \mathrm{a}$ & $83.50 \pm 3.87 \mathrm{a}$ \\
\hline
\end{tabular}

temperature was effective during the "coupling phase" when the far-red phytochrome (Pfr) initiates the processes leading to germination. The data presented here suggest that photoinhibition of spore germination observed at 62 and $42 \%$ light is a consequence of high light levels. Apparently, the results were not influenced by daily temperature oscillation since they were observed at all light levels analyzed in this study.

For Rumohra adiantiformis (G. Forst.) Ching (Dryopteridaceae), the highest germinability was achieved at 9\% light in April and August/2000, at Florianópolis, Santa Catarina state, Brazil; at 54 and $72 \%$ light in March/2000, germination was completely inhibited and partially inhibited at $72 \%$ light in April 2000 (Brum \& Randi 2002). On the other hand, high germinability of Cheilanthes feei Moore was achieved under a continuous light regime of $100 \mu \mathrm{mol} \mathrm{m} \mathrm{m}^{-2} \mathrm{~s}^{-1}$, but this species can germinate under a wide variety of conditions including constant darkness (Nondorf et al. 2003).The authors applied a similar photon flux density to $C$. feei spores in relation to the values registered for Blechnum brasiliense, on the first day of cultivation under $62 \%$ light, when the day was cloudy. The canopy phenomenon which is responsible for the low $\mathrm{Pfr} / \mathrm{P}_{\text {total }}$ under the canopy must be taken into account on forest soils. It results from the fact that green leaves absorb red light because of their high chlorophyll content but are relatively transparent to far-red light (Taiz \& Zeiger 1998). According to Bewley \& Black (1994) photoinhibition of seed germination is a manifestation of the high-irradiance reaction (HIR) as a mechanism for discouraging seed germination under high field irradiance when seedlings would be subjected to harsh drying conditions. Shinomura et al. (1996) explain that seed germination of light-sensitive species is a low fluence response (LFR) controlled by the detection of changes in the red/far-red ratio (R/FR) through phytochrome B (Phy B). Similar photoinhibition behavior could be proposed for spores of Cyathea delgadii and $B$. brasiliense

For Dicksonia sellowiana, lower mean germination time was observed for spores cultivated at 5 and $20 \%$ light in relation to 36 and $50 \%$ light (Renner \& Randi 2004). A different response was observed in the present paper for Blechnum brasiliense and Cyathea delgadii spores, which presented lower mean germination time at high light levels.

The second observation in this paper was gametophyte death for both species at 62 and $42 \%$ light, after a few days of cultivation. This effect was probably a consequence of chlorophyll oxidation at higher light levels, which reduces photosynthetic 


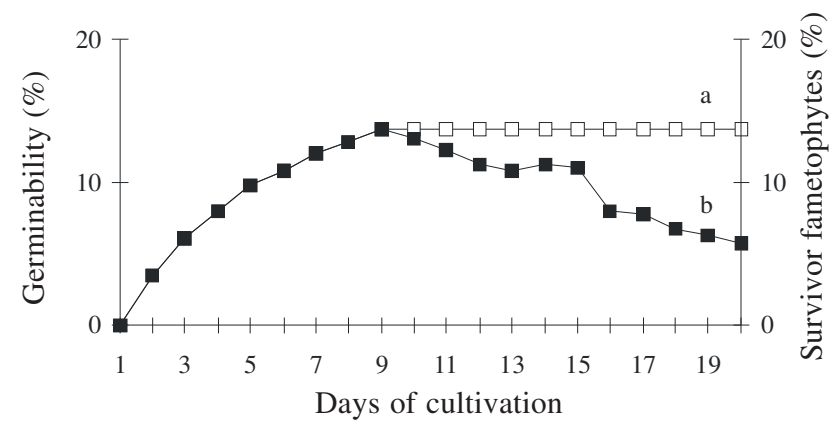

B

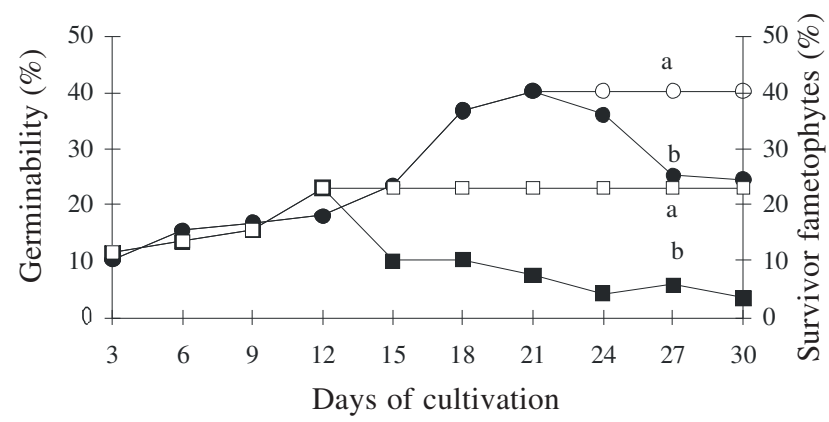

Figure 2. Survivor gametophytes of Blechnum brasiliense Desv. (A) and Cyathea delgadii Sternb. (B). Letters denote statistical differences between germinability and survivor gametophytes (Student $t$ test). Open symbols are germinability. Closed symbols are survivor gametophytes ( $\square=62 \%$ light; $\circ=42 \%$ light).

efficiency, limiting plant growth and eventually causing the death of plants as pointed out by Demming-Adans \& Adams (1992), Sonoike (1996) and Kitao et al. (2000).

Several authors also verified the effects of light levels on the growth of young sporophytes. Suzuki et al. (2005) showed that young Dicksonia sellowiana sporophytes did not survive at 100, 75, and 50\% light at Florianópolis, Santa Catarina state, Brazil. They observed the highest development and fresh mass/dry mass ratio, which reflects the level of water, in plants of D. sellowiana growing at $10 \%$ light. Concerning the effects of light levels on sporophyte development of Alsophila firma (Baker) D.S. Conant and Sphaeropteris horrida (Liebm.) Tryon, members of the Cyatheaceae, Bernabe et al. (1999) concluded that the forest edge was an appropriate habitat for their establishment, where PAR was nine times higher $\left(160 \mu \mathrm{mol} \mathrm{m}^{-2} \mathrm{~s}^{-1}\right)$ than in the forest interior $\left(18 \mu \mathrm{mol} \mathrm{m}^{-2} \mathrm{~s}^{-1}\right)$ on the observation date. Therefore, appropriate light levels and light quality seem to be of fundamental importance for fern establishment, together with water, temperature and nutrient supplies; they must guarantee germination and photosynthetic activity for sporophyte development.

The present data suggest that fern spore photoinhibition is a mechanism that can guarantee spore germination and gametophyte establishment under appropriate environmental conditions. If spores are dispersed in open areas (gaps) they can germinate on cloudy or rainy days, but gametophytes probably will not survive on sunny days. Additional information on the effect of light levels on gametophyte and sporophyte growth will improve the understanding of fern physiology and establishment under natural conditions.
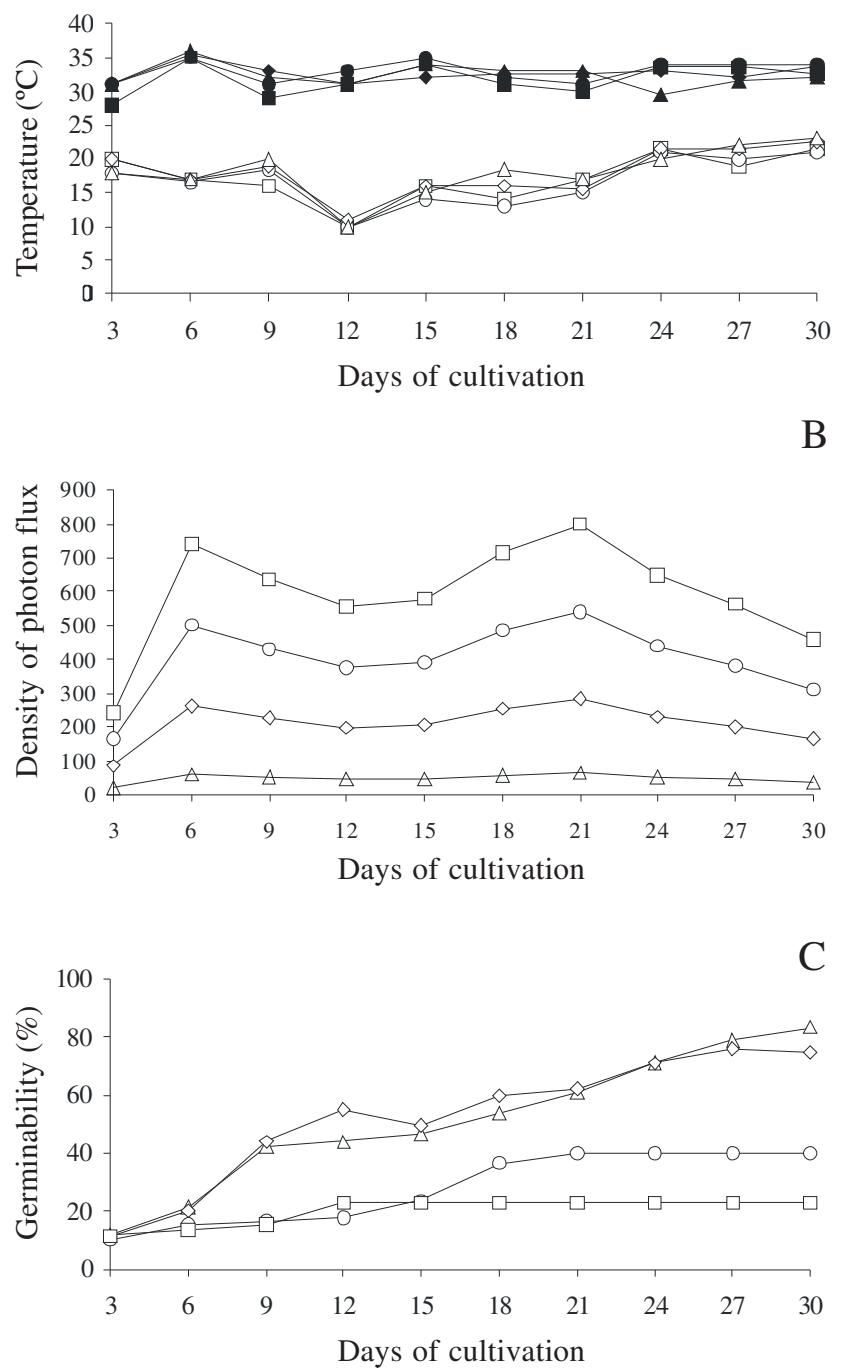

Figure 3. Minimum and maximum temperature (A) and irradiance $\left(\mu \mathrm{mol} \mathrm{m} \mathrm{m}^{-2} \mathrm{~s}^{-1}\right)(\mathrm{B})$ measured at 14:00 h, inside boxes of black shade netting where spores were kept to provide different light levels from 1 to 30 April; germinability of Cyathea delgadii Sternb. (C). Open symbols are minimum temperatures and dark symbols are maximum temperatures ( $\square=62 \%$ light; $\circ=42 \%$ light; $\diamond=22 \%$ light; $\triangle 5 \%$ light). 
914 Hiendlmeyer \& Randi: Response of spores and young gametophytes of Cyathea delgadii Sternb. (Cyatheaceae)...

\section{Acknowledgements}

Rosane Hiendlmeyer thanks the Council of Scientific and Technological Development (CNPq Conselho Nacional de Desenvolvimento Científico e Tecnológico) for the MS grant (Plant Biology Graduation Program - UFSC.)

\section{References}

Bewley, J.D. \& Black, M. 1994. Seeds: physiology of development and germination. New York, Plennum Press.

Bernabe, N.; Williams-Linera G. \& Palacios-Rios, M. 1999. Tree ferns in the interior and at the edge of a Mexican cloud forest remnant: spore germination and sporophyte survival and establishment. Biotropica 31: 83-88.

Brum, F.M.R. \& Randi, A.M. 2002. High irradiance and temperature inhibit the germination of spores of the fern Rumohra adiantiformis (Forst.) Ching (Dryopteridaceae). Revista Brasileira de Botânica 25: 391-396.

Chazdon, R.L. \& Fetcher, N. 1984. Photosynthetic light environmental in a lowland tropical rain forest in Costa Rica. Journal of Ecology 72: 553-564.

Demming-Adans, B. \& Adams, W.I. 1992. Photoprotection and other responses of plants to high light stress. Annual Review of Plant Physiology and Plant Molecular Biology 43: 599-626.

Dyer, A.F. 1979. The culture of fern gametophytes for experimental investigation. Pp. 253-305. In: A.F. Dyer (ed.).The experimental biology of ferns. London, Academic Press.

Fernandes, I. 2000. Taxonomia dos representantes de Dicksoniaceae no Brasil. Pesquisas (Botânica) 50: 5-26.

Filippini, E.C.P.; Duz, S.R. \& Randi, A.M. 1999. Light and storage in the germination of spores of Dicksonia selowiana (Presl.) Hook., Dicksoniaceae. Revista Brasileira de Botânica 22: 21-26.

Furuya, M. 1983. Photomorphogenesis in ferns. Pp. 569-600. In: W. Shropshire \& H. Mohr (eds.). Photomorphogenesis. Encyclopedia of Plant Physiology. Berlin, Springer.

Furuya, M. 1985. Photocontrol of spore germination and elementary process of development in fern gametophytes. Proceedings of the Royal Society of London 86: 13-19.

Haupt, W. 1990. Phytocromo-mediated fern-spore germination: Inhibition by elevated temperatures. Photochemical Photobiology 52: 57-59.

Haupt, W. 1991. Phytochrome-controlled fern-spore germination: phase-specific modulation by elevated temperatures. Photochemical Photobiology 54: 811-818.

Haupt, W. 1992. Phytocrome-mediated fern-spore germination: A temperature-sensitive phase in the transduction chain after action of Pfr. Journal of Plant Physiology 140: 575-81.

Kitao, M.; Lei, T.T.; Koike, T.T.; Tobita, H. \& Maruyama, Y. 2000. Susceptibility to photoinhibition of three deciduous broadleaf tree species with different successional traits raised under various light regimes. Plant Cell and Environment 23: 81-89.
Labouriau, L.G. 1983. A germinação das sementes. Série de Biologia, Monografia 24, Washington, OEA.

Lüttge, U. 1997. Physiological ecology of tropical plants. Berlin, Springer.

Miller, J.H. 1968. Fern gametophytes as experimental material. Botanical Review 34: 361-440.

Mohr, H. 1956. Die Abängikeit des Protonemawatchstums und der Protonemapolarität bei farmen vom licht. Planta 47: $127-156$.

Nondorf, S.L.; Dooley, M.A.; Palmieri, M. \& Swatzell, L.J. 2003. The effects of $\mathrm{pH}$, temperature, light intensity, light quality, and moisture levels on spore germination in Cheilanthes feei of Southeast Missouri. American Fern Journal 93: 56-69.

Raghavan, V. 1993. Cellular and molecular biology of fern haplophase development. Journal of Plant Research (Special Issue) 3: 59-73.

Renner, G.D.R. \& Randi, A.M. 2004. Effect of sucrose and irradiance on germination and early gametophyte growth of the endangered tree fern Dicksonia sellowiana Hook. (Dicksoniaceae). Acta Botanica Brasilica 18: 375-390.

Santana D.G. \& Ranal M.A. 2004. Análise da germinação: um enfoque estatístico. Brasília, Editora UnB.

Sehnem, A. 1977. As filicíneas do Sul do Brasil, sua distribuição geográfica, sua ecologia e suas rotas de migração. Pesquisas (Botânica) 31: 1-108.

Shinomura, T.; Nagatani, A.; Hanzawa, H.; Kubota, M.; Watanabe, M. \& Furuya, M. 1996. Action spectra for phytochrome A and phytochrome B specific photoinduction of seed germination in Arabidopsis thaliana. Proceedings of the National Academy of Sciences 93: 8129-8133.

Sonoike, K. 1996. Photoinhibition of photosystem I: Its physiological significance in the chilling sensitivity of plants. Plant Cell Physiology 37: 239-247.

Sugai, M. \& Furuya, M. 1967. Photomorphogenesis in Pteris vittata. Phytochrome-mediated spore germination and blue light interaction. Plant Cell Physiology 8: 737-748.

Sugai, M. \& Furuya, M. 1968. Photomorphogenesis in Pteris vittata. II. Recovery from blue-light-induced inhibition of spore germination. Plant Cell Physiology 9: 671-680.

Suzuki, C.C.L.F.; Paulilo, M.T. \& Randi, A.M. 2005. Substrate and irradiance affect the early growth of the endangered tropical tree fern Dicksonia sellowiana Hook. (Dicksoniaceae). American Fern Journal 95: 115-125.

Taiz, L. \& Zeiger, E. 1998. Plant physiology. $2^{\text {nd }}$ ed. Sunderland, Sinauer Associates, Inc., Publishers. Pp. 483-516.

Tryon, R.M. 1970. Development and evolution of ferns floras of Oceanic Islands. Biotropica 2: 76-84.

Tryon, R.M. 1972. Endemic areas and geographic speciation in Tropical American ferns. Biotropica 4: 121-131.

Tryon, R.M. \& Tryon, A.F. 1982. Fern and allied plants with special reference to Tropical America. New York, Springer.

Windisch, P.G. 2002. Fern conservation in Brazil. Fern Gazette 16: 295-300. 